\title{
Development of Therapeutic Food for Adolescent Girls
}

\author{
B.J.V. Sai Vinay ${ }^{1}$, G. Rajender $^{2 *}$, Ch. Wagdevi ${ }^{3}$, G. Sandya Rani $^{4}$ and Y.V. Revathi $^{4}$ \\ ${ }^{1}$ Department of Agricultural Engg., Aditya Engineering College, East Godavari, A.P., India \\ ${ }^{2}$ Department of Processing \& Food Engg., College of Agricultural Engineering, \\ Sangareddy, PJTSAU, TS, India \\ ${ }^{3}$ Department of Agricultural Engineering Siddartha Engineering College, Tirupathi, AP, India \\ ${ }^{4}$ College of Agricultural Engineering, Madakasira, Anantapur, ANGRAU, India \\ *Corresponding author
}

\begin{tabular}{|l|}
\hline Key w or d s \\
Therapeutic food, \\
RDA (Required \\
Dietary \\
Allowances), \\
Adolescents, Soya \\
bean, High protein \\
etc. \\
\hline Article Info \\
\hline Accepted: \\
12 May 2019 \\
Available Online: \\
10 June 2019 \\
\hline \hline
\end{tabular}

\section{A B S T R A C T}

Adolescents constitute over $21.4 \%$ of the population in India. This age group needs special attention as is a period of rapid transition from childhood to adulthood that normally is characterized by important psychological and social changes in the age group of $10-19$ years. The adolescents number is expected to reach 1.13 billion by the year 2025 . It is during the period of adolescence that nutrient needs are the greatest. Hence, the specific objectives of our study are to identify the key nutritional problems that affect adolescents and to develop a therapeutic food fulfilling their requirements. The present study was undertaken for the preparation and evaluation of a therapeutic food for Adolescent girls formulated with Bengal gram, Soya bean, Barley, Green gram, wheat and Ragi. Experiments were carried out in the Quality control lab, Andhra Pradesh Foods Pvt. Ltd. to study their chemical composition and overall acceptability. All the formulations were prepared according to the RDA requirements for adolescent girls. The therapeutic food formulated with Soya bean, Ragi and Green gram of $16 \mathrm{~g}, 18 \mathrm{~g}$, and $30 \mathrm{~g}$ respectively has attained the high levels of nutritional properties values but lower organoleptic properties. The formulation with composition of $17 \mathrm{~g}$ of soya bean, $18 \mathrm{~g}$ of barley and $30 \mathrm{~g}$ of green gram has attained good nutritional values and highest acceptability in terms of hedonic rating. This formulated sample is highly preferable to adolescent girls suffering from anemia, stomach pain and nerves weakness patients as the food contains high amount of iron and the soya bean acts as the nutritional supplement to the growing adolescents.

\section{Introduction}

The term youth encompasses ages 10 to 24 years, while the term adolescents as defined by WHO (1986) includes persons aged 10-19 years. Adolescents are sometimes designated as 'children', for instance, in the UN
Convention on the Rights of the Child of 1989, which applies to all individuals below 18 years of age. The period of gradual transition from childhood to adulthood that normally begins with the onset of signs of puberty, is characterized by important psychological and social changes. 
Adolescents are far from being a homogeneous group, in terms of development, maturity and lifestyle. Adolescence may be divided into three developmental stages based on physical, psychological and social changes.

Early adolescence, 10/13-14/15 years;

Mid adolescence, 14/15-17 Years;

Late adolescence, between 17-21 years, but variable.

Being in transition, adolescents may no longer benefit from the attention and care that usually go to children, but they may not get the protections associated with adulthood either. In developing countries, adolescents have an even higher demographic weight, for instance, roughly 26\% in Salvador, compared to $14 \%$ in USA (Burt 1996). Similarly, in the Philippines, it is estimated that adolescents represent one quarter of the total population (Bouis et al., 1998). In 1995, there were 914 million adolescents living in the developing world, that is, $85 \%$ of the total (United Nations 1997). Their number is expected to reach 1.13 billion by the year 2025 . Adolescence is a period of rapid growth: up to $45 \%$ of skeletal growth takes place and 15 to $25 \%$ of adult height is achieved during adolescence (Rees and Christine, 1989. Nutrition influences growth and development throughout infancy, childhood and adolescence. It is, however, during the period of adolescence that nutrient needs are the greatest (Lifshitz, Tarim and Smith, 1993).Psychological and social aspects of adolescents development are less often described in connection with adolescent health than their physical growth and maturation characteristics (Gillespie 1997). However, recent studies have shown that the prevalence of malnutrition and anaemia is high in these age groups. Menarche is a complex of growing up. From both medical and social perspectives, it is often considered as the central event of female puberty, as it suggests the possibility of fertility. Menarche further calls for special attention because of the physical and emotional problems associated with it. Though the menstrual cycle is a normal monthly function of a healthy female body, the main concern is delayed menstruation, irregular cycles pertaining to hormonal fluctuations and pain during menses which is felt in uterus and stomach. Since the International Youth Year of 1985 with its focus on adolescent issues in general and in the area of health in particular, has grown dramatically. Unfortunately, the assessment of the nutritional status of adolescent girls has been the least explored area of research, particularly in rural India. Hence, the present study was done with the objective of development of therapeutic food for the adolescent age group in India which fulfils the deficiencies and decreases nutritional problems of this segment.

\section{Identification of nutritive problems in adolescent girls}

In Adolescent Girls so many problems is prevented.Mainly1n adolescent girls 80-90\% suffering some of the problems undertaken are following.

Stomach pain

Back pain

Nerves weakness

Lack of blood (Anemia)

Eye sight

under weight

Obesity.

\section{Stomach pain}

It is caused due to lack of vitamin deficiency like niacin, B12 and Mineral deficiency caused due to potassium, Magnesium. 


\section{Back pain}

It is caused due to lack of vitamin and minerals like Vitamin D and magnesium.

\section{Nerves weakness}

It is caused due to lack of vitamin deficiency in vitamin $\mathrm{E}$, vitamin $\mathrm{B} 12$ and some of the mineral deficiency caused by magnesium and minor quantities of potassium, vitamin D.

\section{Low blood levels}

It is due to lack of Iron, magnesium, B12, Folate, Zinc.

\section{Eyesight}

It is due to lack of Vitamin A, Vitamin D and Minerals due to Magnesium, B12.

\section{Obesity}

It is due to lack of vitamin D, vitamin A. minerals due to magnesium, B12, Iodine

\section{Underweight}

It is due to lack of vitamin D and B12 mineral deficiency.

\section{Materials and Methods}

The following procedure/process is followed for development of Therapeutic food.

\section{Selection of raw ingredients}

The following raw materials were selected for preparing therapeutic food for adolescent girls.

Green gram

Barley

Bengal gram
Soya bean

Ragi

Wheat

Sugar

Refined Palmolein Oil (RPO)

Vitamin premix

Iron

Magnesium

Zinc

Niacin

Vitamin B

Vitamin D

Vitamin E

The nutritive values of raw materials are tabulated as follows.

\section{Cleaning}

In the cleaning machine, dust and extraneous material are removed by sieving by graded screens. Stones are also separated manually. All the raw materials are cleaned thoroughly.

\section{Roasting}

The raw materials are roasted at a temp of $110^{0} \mathrm{C}$ in order to increase the aroma. Roasting imparts brown colour to raw material due to browning reactions. It also adds increase in acceptability. Roasting decreases the moisture content which helps in increasing the shelf life food product. Flavour changes due to roasting also increases its overall acceptability.

\section{Nutritive values of roasted raw materials}

The Nutritive values of roasted raw materials are given in the table 3 .

\section{Milling}

All the roasted raw materials are grinded to a size of $0.01 \mathrm{~mm}$ using disc mill. It consists of no. discs which revolve along vertical axis. 
The sharp periphery of discs helps in cutting or grinding the raw material. The raw material is fed at the head of the disc mill. The finely ground flours are received from the front cylindrical like opening attached the body of disc mill.

\section{Formulation for preparation of therapeutic food samples}

As per the RDA (Required Dietary Allowances) norms the following are the requirements prescribed for adolescent girls in view of their nutrition. The recommended requirements are tabulated as follows. Hence, the total calories required per day for an adolescent girl is $2368 \mathrm{kcal} /$ day and energy supplied due to protein should be 10-30\% i.e. 236- $710 \mathrm{kcal}$. Energy supplied due to carbohydrates should be $40-65 \%$. i.e. 1065 $1539 \mathrm{kcal}$. Energy supplied due to fat should be $20-34 \%$ i.e. $473-805 \mathrm{kcal}$. The energy levels supplied is divided by factor of 5 so that the food on consumption to 5 times the required energy levels will be attained. So, as 1 gram of protein give 4 kilo calories and 1 gram of carbohydrate gives 4 kilo calories on dividing the energy supplied due to protein and carbohydrates by 4 we will get the required protein and carbohydrate ranges in 11-35grams and carbohydrates 42 -65grams. Similarly, as 1 gram of fat supplies 9 kilo calories of energy, on dividing the energy supplied due to fat by 9 we will get the no. of grams of fat to be supplied. It will be in the range of 10-17 grams.

Hence, required ranges of protein, carbohydrates and fat are

Protein: 11-35 grams

Carbohydrates: 40-65 grams

Fat: $10-17$ grams

So to standardize the nutritive contents, we have taken the middle values in the ranges mentioned above. Hence the nutritive proportion maintained is as follows

Protein: 18grams

Carbohydrates: 63 grams

Fat: 14 grams

According to RDA recommendations, any such proportion in the above ranges is suitable for adolescent girls. So there will be a many such proportions which can be developed.

Now, keeping these nutritive values constant for all our samples, we developed equations in order to determine the composition of the sample (Fig. 1-6).

For the preparation of sample 1, the following ingredients were selected.

1. Soya bean

2. Barley

3. Green gram

4. $\quad$ Refined Palmolein oil

5. Sugar

6. Vitamin Premix

Formulas to figure out amount of ingredients required are as follows

$$
\begin{aligned}
& 0.44 x+0.12 y+0.26 z=18 g(\text { Protein }) \ldots(1) \\
& 0.20 x+0.01 y+0.01 z=4 g(\text { Fat }) \ldots(2) \\
& 0.21 x+0.76 y+0.64 z=38 g \\
& (\text { Carbohydrates)..(3) }
\end{aligned}
$$

Where $\mathrm{x}$ is Soya bean, $\mathrm{y}$ is Barley and $\mathrm{z}$ is green gram

On solving the above equations the amount of ingredients required are found as follows

$\mathrm{x}=17.49 \mathrm{~g}, \mathrm{y}=18.34 \mathrm{~g}$ and $\mathrm{z}=30.50 \mathrm{~g}$.

The composition of sample 1 is given below 
For the preparation of sample 2, the following ingredients were selected.

Soya bean

Bengal gram

Green gram

Refined Palmolein oil

Sugar

Vitamin premix

Formulas to figure out amount of ingredients required are as follows

$0.23 x+0.44 y+0.26 z=18 g($ Protein $) \ldots(1)$

$0.05 x+0.20 y+0.01 z=4 g($ Fat $) \ldots(2)$

$0.61 \mathrm{x}+0.21 \mathrm{y}+0.64 \mathrm{z}=38 \mathrm{~g}$

(Carbohydrates)...(3)

Where $\mathrm{x}$ is Soya bean, $\mathrm{y}$ is Bengal gram and $\mathrm{Z}$ is green gram

On solving the above equations the amount of ingredients required are found as follows

$\mathrm{x}=39.42 \mathrm{~g}, \mathrm{y}=9.20 \mathrm{~g}$, and $\mathrm{z}=18.17 \mathrm{~g}$

The composition of sample -2 is given below

For the preparation of sample 3, the following ingredients were selected.

Soya bean

Wheat

Green gram

Refined Palmolein oil

Sugar

Vitamin premix

Formulas to figure out amount of ingredients required are as follows

$$
\begin{aligned}
& 0.44 x+0.12 y+0.26 z=18 g(\text { Protien }) \ldots(1) \\
& 0.20 x+0.01 y+0.01 z=4 g(\text { Fat }) \ldots(2)
\end{aligned}
$$

$0.21 \mathrm{x}+0.82 \mathrm{y}+0.64 \mathrm{z}=38 \mathrm{~g}$

(Carbohydrates)...(3)

Where $\mathrm{x}$ is Soyabean, $\mathrm{y}$ is wheat and $\mathrm{z}$ is green gram

On solving the above equations the amount of ingredients required are found as follows

$\mathrm{x}=17.56 \mathrm{~g}, \mathrm{y}=17.20 \mathrm{~g}$, and $\mathrm{z}=31.57 \mathrm{~g}$.

The composition of sample -3 is given below

For the preparation of sample 4, the following ingredients were selected.

Soya bean

Ragi

Green gram

Vitamin premix

Refined palmolein oil

Formulas to figure out amount of ingredients required are as follows

$0.23 x+0.44 y+0.26 z=18 g \ldots(1)$

$0.05 x+0.20 y+0.01 z=4 g \ldots(2)$

$0.61 x+0.21 y+0.64 z=38 g \ldots(3)$

Where $\mathrm{x}$ is Soyabean, $\mathrm{y}$ is raghi and $\mathrm{z}$ is green gram

On solving the above equations the amount of ingredients required are found as follows $\mathrm{X}=$ $39.42 \mathrm{~g}, \mathrm{Y}=9.20 \mathrm{~g}$, and $\mathrm{Z}=18.17 \mathrm{~g}$

The composition of sample -4 is given below

\section{Blending}

All the flours prepared from roasted raw materials are now well mixed manually. Refined palmolein oil is used for proper mixing of flours. All the flours are blended 
according to the developed formulas in small quantities.

\section{Final product}

Finally, the final products (Four samples) were obtained by uniformly blending all the flours to an extent up to which all the raw materials are uniformly distributed (Fig. 7).

\section{Analysis of quality parameters}

\section{Determination of moisture content}

5-10 grams of samples were taken Petridishes and kept in hot air oven at $105 \pm 1{ }^{\circ} \mathrm{C}$ for 4 hours. Then allowed sample to cool in a desiccator and weighed it.

\section{Calculation}

$\%$ Moisture $=\frac{\left(\mathrm{W}_{2}-\mathrm{W}_{3}\right)}{\left(\mathrm{W}_{2}-\mathrm{W}_{1}\right)} \times 100$

Where

$\mathrm{W}_{1}$ - Wt of empty Petri dish.

$\mathrm{W}_{2}$ - Wt of Petri dish cum sample before drying.

$\mathrm{W}_{3}-\mathrm{Wt}$ of Petri dish cum sample after drying

\section{Determination of protein content}

Protein estimation of sample was carried out using kjeldhal method.

\section{Calculation}

Protein contain $=\frac{\mathrm{TV} \times 1.4007 \times 6.25 \times \mathrm{N}}{\text { Weight of the sample }}$

Where
6.25 - Conversation factor

$\mathrm{N}$ - Normality of $\mathrm{NaoH}$ Solution

TV - Titration value

\section{Determination of fat}

Fat was estimated by Soxhlet apparatus method. Take an empty thimble weight. Weigh the empty thimble with logos of 5 grams of sample and weigh the thimble. Difference in weight gives sample weight. Weight the empty Soxhlet flask with boiling stone. Keep the thimble in Soxhlet flask. Pour the solvent (150 $\mathrm{ml}$ of hexane) into the Soxhlet flask. Fix the Soxhlet flask in Soxhlet extraction apparatus with a reflux condenser. Keep the total arrangement of process for at least 4-5 hours. After 4 hours take out the solvent from hexane and thimble from extraction apparatus. Keep the Soxhlet flask in the hot air oven for 10 minutes to evaporate the solvent and cool it in desiccator. Then weigh the flask with extracted fat.

$\%$ Fat content $=\frac{\left(\mathrm{W}_{3}-\mathrm{W}_{2}\right)}{\left(\mathrm{W}_{1}-\mathrm{W}\right)} \times 100$

Where:

W - Weight of empty thimble

$\mathrm{W}_{1}$ - Weight of thimble with sample

$\mathrm{W}_{2}$ - Weight of empty Soxhlet flask

$\mathrm{W}_{3}$ - Weight of Soxhlet flask with extracted fat

Estimation of carbohydrate content (Anthrone method)

\section{Procedure}

1. Weigh $100 \mathrm{mg}$ of sample and place it in boiling test tube.

2. Hydrolyze by keeping it in a boiling water bath for $3 \mathrm{hrs}$ with $5 \mathrm{ml}$ of $5 \mathrm{~N} \mathrm{HCl}$ and cooled to room temperature. 
3. Neutralize it with solid $\mathrm{Na}_{2} \mathrm{CO}_{3}$ until the effervescence ceases.

4. Make up the volume to $100 \mathrm{ml}$ and then centrifuge.

5. Collect the supernatant and take $0.5 \mathrm{ml}$ and $1 \mathrm{ml}$ aliquots.

6. Prepare the standards by taking $0.2 \mathrm{ml}$, $0.4 \mathrm{ml}, 0.6 \mathrm{ml}, 0.8 \mathrm{ml}, 1 \mathrm{ml}$ and run a blank.

7. Make up the volume in all the tubes to $1 \mathrm{ml}$ with distilled water.

8. Then add $4 \mathrm{ml}$ of Anthrone reagent and heat for $8 \mathrm{~min}$ in a boiling water bath.

9. Cool the tubes under tap waterand read the green color at wave length $630 \mathrm{~nm}$.

10. Draw a standard curve by plotting concentration of standard on $\mathrm{X}$-axis and absorbance on $\mathrm{Y}$ - axis.

11. From the graph calculate the amount of carbohydrates present in the sample tube.

\section{Calculation}

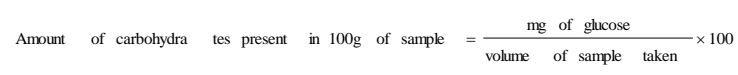

\section{Sensory analysis}

The sensory evaluation was carried out on nine point Hedonic scale as shown in Appendix with ' 1 ' being lowest possible value and '9' being highest possible value.

It includes evaluating product quality based on colour, texture, flavour and overall acceptability of the product.

Nine point Hedonic scale was used for quality evaluation on the basis of colour, texture, flavour and overall acceptability.

\section{Statistical analysis- Student's t-test}

Any statistical test that uses the t-distribution can be called a t-test. One of the most common is Student's t-test, named after "Student," the pseudonym that William Gosset used to hide his employment by the Guinness brewery in the early 1900's (they didn't want their competitors to know that they were making better beer with statistics). Student's t-test is used to compare the means of two samples, even if they have different numbers of replicates. In simple terms, the $t$ test compares the actual difference between two means in relation to the variation in the data (expressed as the standard deviation of the difference between the means).

\section{Procedure}

1. List the data for sample (or treatment) 1. 2. List the data for sample (or treatment) 2 .

3. Record the number $(n)$ of replicates for each sample (the number of replicates for sample 1 being termed $n_{1}$ and the number for sample 2 being termed $n_{2}$ )

4. Calculate mean of each sample ( $\bar{x}_{1}$ and $\left.\bar{x}_{2}\right)$.

5. Calculate standard deviation of each sample $\left(s_{1}\right.$ and $\left.s_{2}\right)$

6. Calculate the t-value as follows

$$
t=\frac{\bar{X}_{1}-\bar{X}_{2}}{\sqrt{\frac{1}{n_{1}}+\frac{1}{n_{2}}} \sqrt{\frac{\left[\left(n_{1}-1\right) s_{1}^{2}+\left(n_{2}-1\right) s_{2}^{2}\right]}{\left(n_{1}+n_{2}-2\right)}}}
$$

7. Calculate degree of freedom as follows $\mathrm{DF}=\left(n_{1}+n_{2}-2\right)$

8. Enter the $t$-table at degrees of freedom; choose the level of significance required and read the tabulated $t$ value. 
9. If the calculated $t$ value exceeds the tabulated value we say that the means are significantly different at that level of probability

10. Statistical tests allow us to make statements with a degree of precision, but cannot actually prove or disprove anything.

A significant result at the $95 \%$ probability level tells us that our data are good enough to support a conclusion with $95 \%$ confidence. In biological work we accept this level of significance as being reasonable.

\section{Results and Discussion}

\section{Analysis of quality parameters}

During the evaluation of following parameters, each sample was analyzed for three times and average value was considered as final.

\section{Moisture content}

The moisture contents of all samples were found as 2.93, 2.95, 2.92, $2.967 \%$ for sample -1 , sample -2 , sample -3 and sample-4 respectively.

The moisture content for therapeutic food for adolescent girls should not be more than 3\% in order to maintain a good shelf life.

\section{Protein content}

The average protein contents of sample 1, sample 2, sample 3, and sample 4 after analyzing were found to be 17.932, 17.89, 17.83, 17.98 grams respectively whereas theoretically, they were estimated to be 17.933, 17.939, 18.075, 18.001grams respectively. The protein content for therapeutic food for adolescent girls should be 18 gram in order to maintain a good metabolism in adolescents. The protein contents of different samples were plotted graphically in a bar graph for in-depth watch of variations (Fig. 8).

Theoretically, an attempt was made to maximize the protein content to 18 grams during the development of product.

There was no significant difference found in between theoretical and practical values for protein content which was found by the student t-test.

\section{Fat content}

The fat contents of sample 1, sample 2, sample 3 and sample 4 after analyzing were found to be 13.78, 13.87, 13.874, 13.923g respectively whereas theoretically, they were estimated to be 14.192, 14.196, 14.259, $14.094 \mathrm{~g}$ respectively. The fat content for therapeutic food for adolescent girls should be $14 \mathrm{~g}$ in order to maintain good digestive life. The fat contents of different samples were plotted graphically in a bar graph for in-depth watch of variations among the four samples which are formulated with different ingredients.

The least value was obtained for sample 3, $(13.874 \mathrm{~g})$. The variations of Fat contents of various samples were shown in Figure 9.

Theoretically, in the designed product the fat content was controlled to $14 \mathrm{~g}$. Practically it was almost achieved. Among the four samples, sample 4 obtained the maximum value $(13.923 \mathrm{~g})$ and sample 3 was the least (13.78g). Practically, among the four samples, we obtained the maximum value for sample 4 , (13.92g). There was no significant difference found in between theoretical and practical values for fat content which was found by the student t-test. The student t-test was done according to standard procedure. 
Table.1 Vitamin \& mineral deficiencies for various health problems

\begin{tabular}{|c|l|c|c|}
\hline SI. No & \multicolumn{1}{|c|}{ Health problem } & Vitamins & Minerals \\
\hline 1. & Stomach pain & Niacin, B12 & $\begin{array}{c}\text { Potassium, } \\
\text { Magnesium }\end{array}$ \\
\hline 2. & Back pain & Vitamin D & Magnesium \\
\hline 3. & Anemia & B12 & Magnesium, \\
\hline 4. & Nerves weakness & Vitamin E, Vitamin B12 & Magnesium \\
\hline 5. & Underweight & Vitamin D, B12 & ---- \\
\hline 6. & Obesity & Vitamin D, Vitamin A, B12 & Magnesium, \\
\hline & & & Iodine. \\
\hline 7. & Eyesight & Vitamin A, Vitamin D & Magnesium \\
\hline
\end{tabular}

Table.2 Nutritive values of raw materials per $100 \mathrm{~g}$

\begin{tabular}{|c|c|c|c|c|c|c|}
\hline Raw materials & $\begin{array}{c}\text { Moisture } \\
(\mathbf{\%})\end{array}$ & $\begin{array}{c}\text { Protein } \\
(\mathbf{g})\end{array}$ & $\begin{array}{c}\text { Fat } \\
(\mathbf{g})\end{array}$ & $\begin{array}{c}\text { Carbohydrates } \\
(\mathbf{g})\end{array}$ & $\begin{array}{c}\text { Fibre } \\
(\mathbf{g})\end{array}$ & $\begin{array}{c}\text { Minerals } \\
(\mathbf{g})\end{array}$ \\
\hline Bengal Gram & 7 & 23 & 5 & 61 & 1 & 2 \\
\hline Soya bean & 5 & 44 & 20 & 21 & 4 & 5 \\
\hline Barley & 5 & 12 & 1 & 76 & 4 & 1 \\
\hline Wheat & 4 & 12 & 1 & 82 & 0 & 1 \\
\hline Green gram & 4 & 26 & 1 & 64 & 1 & 3 \\
\hline Ragi & 5 & 11 & 2 & 78 & 2.12 & 2.12 \\
\hline Sugar & 5 & 11 & 2 & 100 & 2.12 & 2.12 \\
\hline RPO & - & - & 100 & - & - & - \\
\hline
\end{tabular}

Table.3 Nutritive values of roasted raw materials

\begin{tabular}{|c|c|c|c|c|c|c|}
\hline Raw materials & $\begin{array}{c}\text { Moisture } \\
(\boldsymbol{\%})\end{array}$ & $\begin{array}{c}\text { Protein, } \\
(\mathbf{g m s})\end{array}$ & $\begin{array}{c}\text { Fat, } \\
(\mathbf{g m s})\end{array}$ & $\begin{array}{c}\text { Carbohydrates, } \\
(\mathbf{g m s})\end{array}$ & $\begin{array}{c}\text { Fibre, } \\
(\mathbf{g m s})\end{array}$ & $\begin{array}{c}\text { Minerals, } \\
(\mathbf{g m s})\end{array}$ \\
\hline Bengal Gram & 7 & 23 & 5 & 61 & 1 & 2 \\
\hline Soya bean & 5 & 44 & 20 & 21 & 4 & 5 \\
\hline Barley & 5 & 12 & 1 & 76 & 4 & 1 \\
\hline Wheat & 4 & 12 & 1 & 82 & 0 & 1 \\
\hline Green gram & 4 & 26 & 1 & 64 & 1 & 3 \\
\hline Ragi & 5 & 11 & 2 & 78 & 2.12 & 2.12 \\
\hline Sugar & 5 & 11 & 2 & 100 & 2.12 & 2.12 \\
\hline Rpo & - & - & 100 & - & - & - \\
\hline
\end{tabular}


Table.4 Required Dietary Allowances (RDA) for adolescent girls:

\begin{tabular}{|c|c|}
\hline \multicolumn{2}{|c|}{ RDA requirements for Adolescent girls } \\
\hline Protein & 46 g/day \\
\hline $\mathrm{CHO}$ & $130 \mathrm{~g} /$ day \\
\hline Fat & 22 g/day \\
\hline Calories & $\begin{array}{c}2368 \mathrm{kcal} / \text { day } \\
\text { Energy supplied due to } \\
\text { Protein: } 10 \% \text { to } 30 \% \text {. } \\
\text { Carbohydrates: } 45 \% 65 \% \text {. } \\
\text { Fat: between } 25 \% \text { and } 34 \% \text {. } \\
\text { Calcium: } 1,300 \text { milligrams. } \\
\text { Fiber: } 26 \text { grams. } \\
\text { Sodium: no more than } 1,500 \text { milligrams. }\end{array}$ \\
\hline Niacin & $14 \mathrm{mcg}$ \\
\hline Vitamin b12 & $2.4 \mathrm{mcg}$ \\
\hline Vitamin d & $15 \mathrm{mcg}(600 \mathrm{IU})$ \\
\hline Vitamin E & $15 \mathrm{mcg}$ \\
\hline Iron & $15 \mathrm{mcg}$ \\
\hline Potassium & $4700 \mathrm{mg}$ \\
\hline Magnesium & $360 \mathrm{mg} /$ day \\
\hline Zinc & $9 \mathrm{mg} /$ day \\
\hline
\end{tabular}

Table.5 Composition of sample - 1

\begin{tabular}{|c|c|}
\hline Material & Composition \\
\hline Soyabean & $17 \mathrm{~g}$ \\
\hline Barley & $18 \mathrm{~g}$ \\
\hline Green gram & $30 \mathrm{~g}$ \\
\hline Refined Palmolein oil & $9 \mathrm{~g}$ \\
\hline Sugar & $25 \mathrm{~g}$ \\
\hline Vitamin premix & $1 \mathrm{~g}$ \\
\hline Total & $100 \mathrm{~g}$ \\
\hline
\end{tabular}

Table.6 Composition of sample - 2

\begin{tabular}{|c|c|}
\hline Material & Composition \\
\hline Soyabean & $09 \mathrm{~g}$ \\
\hline Bengal gram & $38 \mathrm{~g}$ \\
\hline Green gram & $18 \mathrm{~g}$ \\
\hline Refined Palmolein oil & $9 \mathrm{~g}$ \\
\hline Sugar & $25 \mathrm{~g}$ \\
\hline Vitamin premix & $1 \mathrm{~g}$ \\
\hline Total & $100 \mathrm{~g}$ \\
\hline
\end{tabular}


Table.7 Composition of sample - 3

\begin{tabular}{|c|c|}
\hline Material & Composition \\
\hline Soyabean & $17 \mathrm{~g}$ \\
\hline Wheat & $17 \mathrm{~g}$ \\
\hline Green gram & $31 \mathrm{~g}$ \\
\hline Refined Palmolein oil & $9 \mathrm{~g}$ \\
\hline Sugar & $25 \mathrm{~g}$ \\
\hline Vitamin premix & $1 \mathrm{~g}$ \\
\hline Total & $100 \mathrm{~g}$ \\
\hline
\end{tabular}

Table.8 Composition of sample - 4

\begin{tabular}{|c|c|}
\hline Material & Composition \\
\hline Soyabean & $16 \mathrm{~g}$ \\
\hline Ragi & $18 \mathrm{~g}$ \\
\hline Green gram & $30 \mathrm{~g}$ \\
\hline Refined Palmolein oil & $9 \mathrm{~g}$ \\
\hline Sugar & $25 \mathrm{~g}$ \\
\hline Vitamin premix & $1 \mathrm{~g}$ \\
\hline Total & $100 \mathrm{~g}$ \\
\hline
\end{tabular}

Note: In all samples, sugar and refined palmolein oil are kept constant to get good sweetens, taste and proper blending.

Fig.1 Flow chart of procedure of making of food product

Raw material (Soyabean, Barley, Green Gram, Bengal gram, Wheat, Jowar)

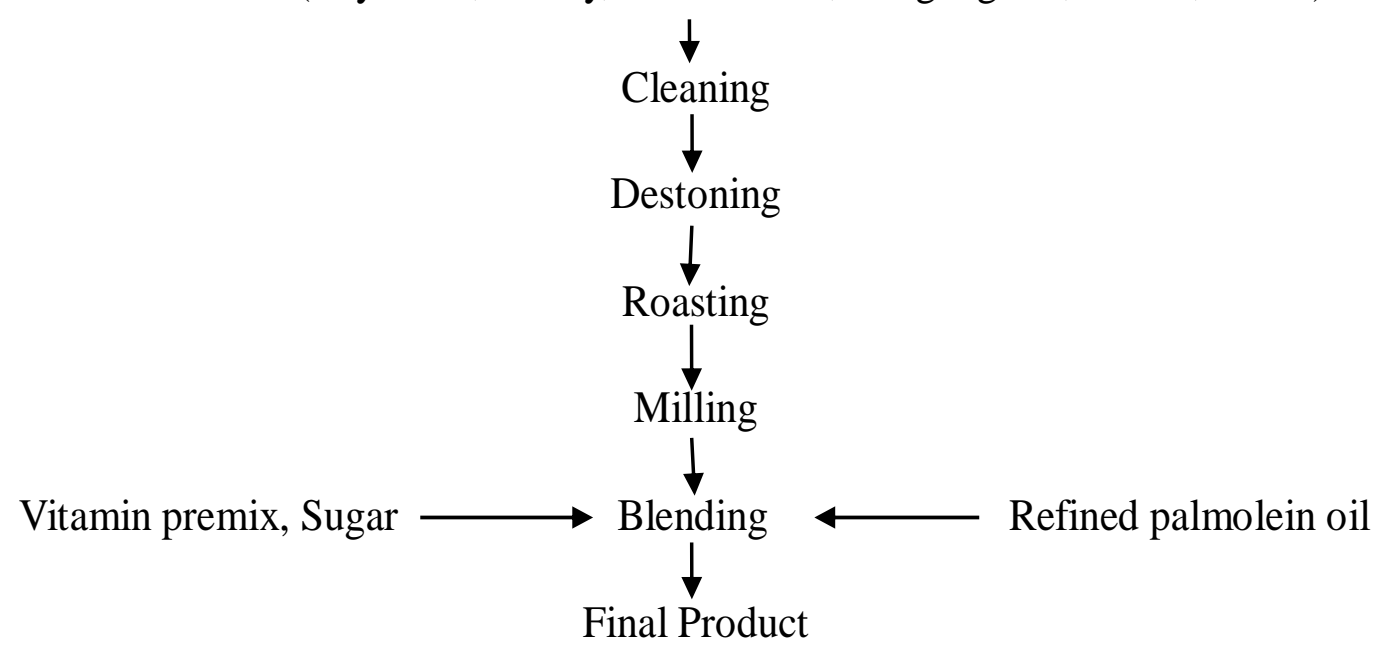


Fig.2 Cleaning of raw materials

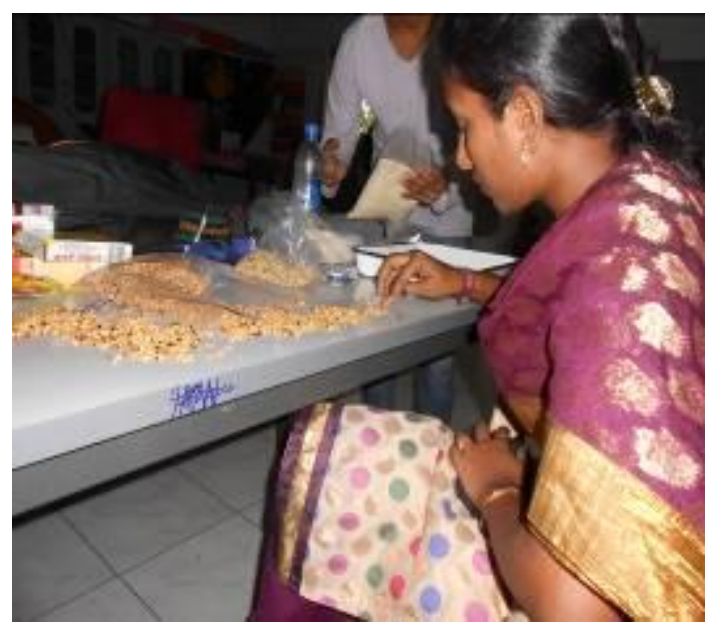

Fig.4 Disc mill

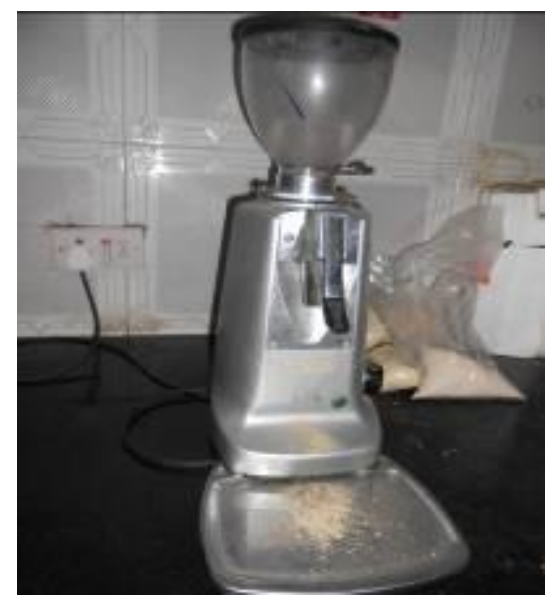

Fig.3 Roasting of raw materials

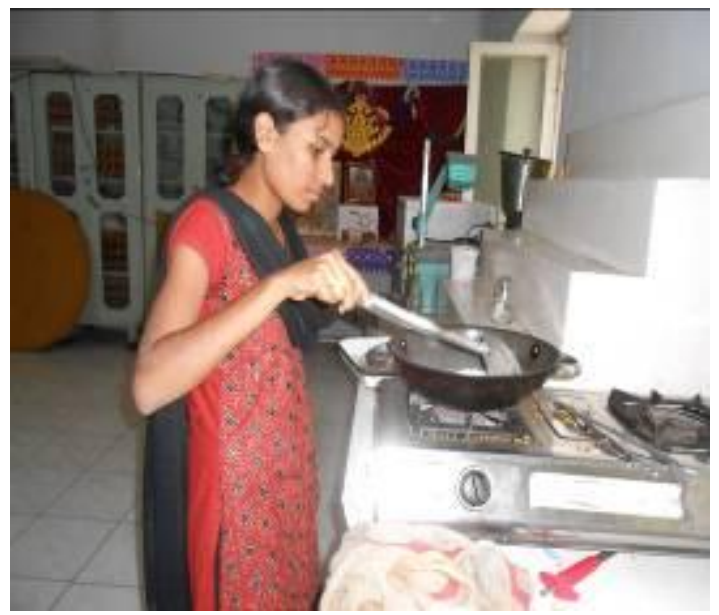

Fig.5 Milling of roasted samples

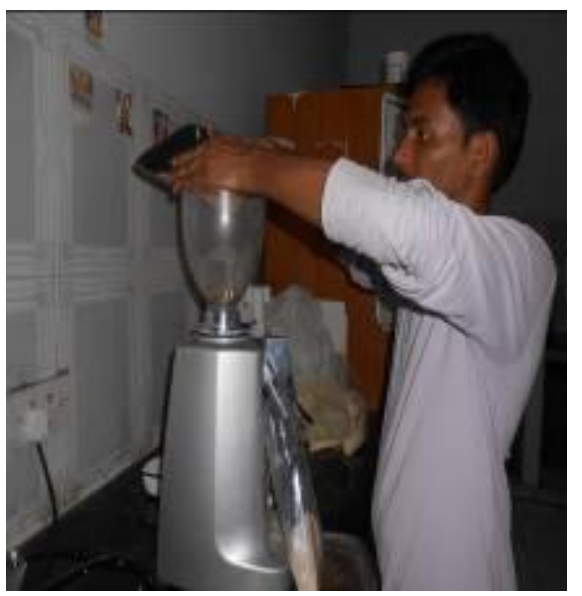

Fig.6 Blending

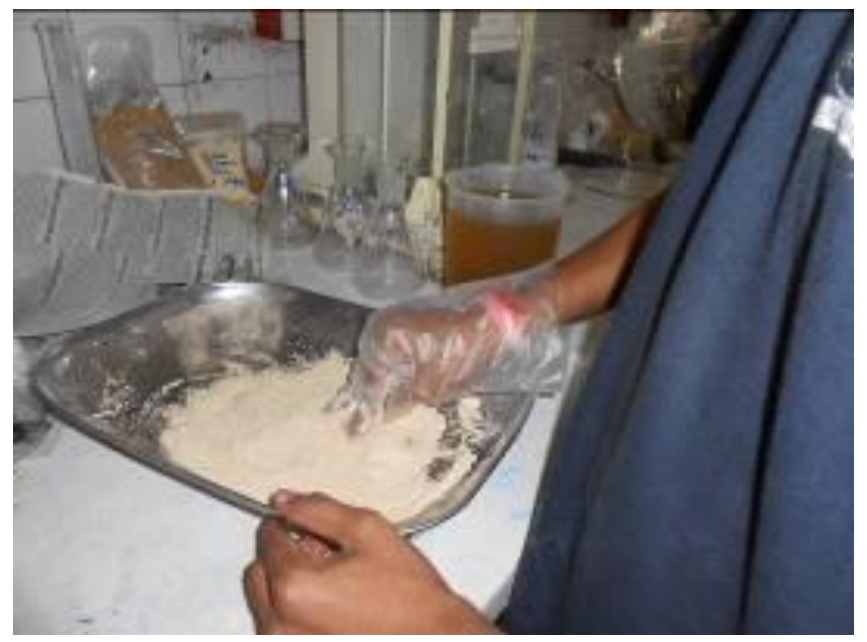


Fig.7 Four Therapeutic food samples

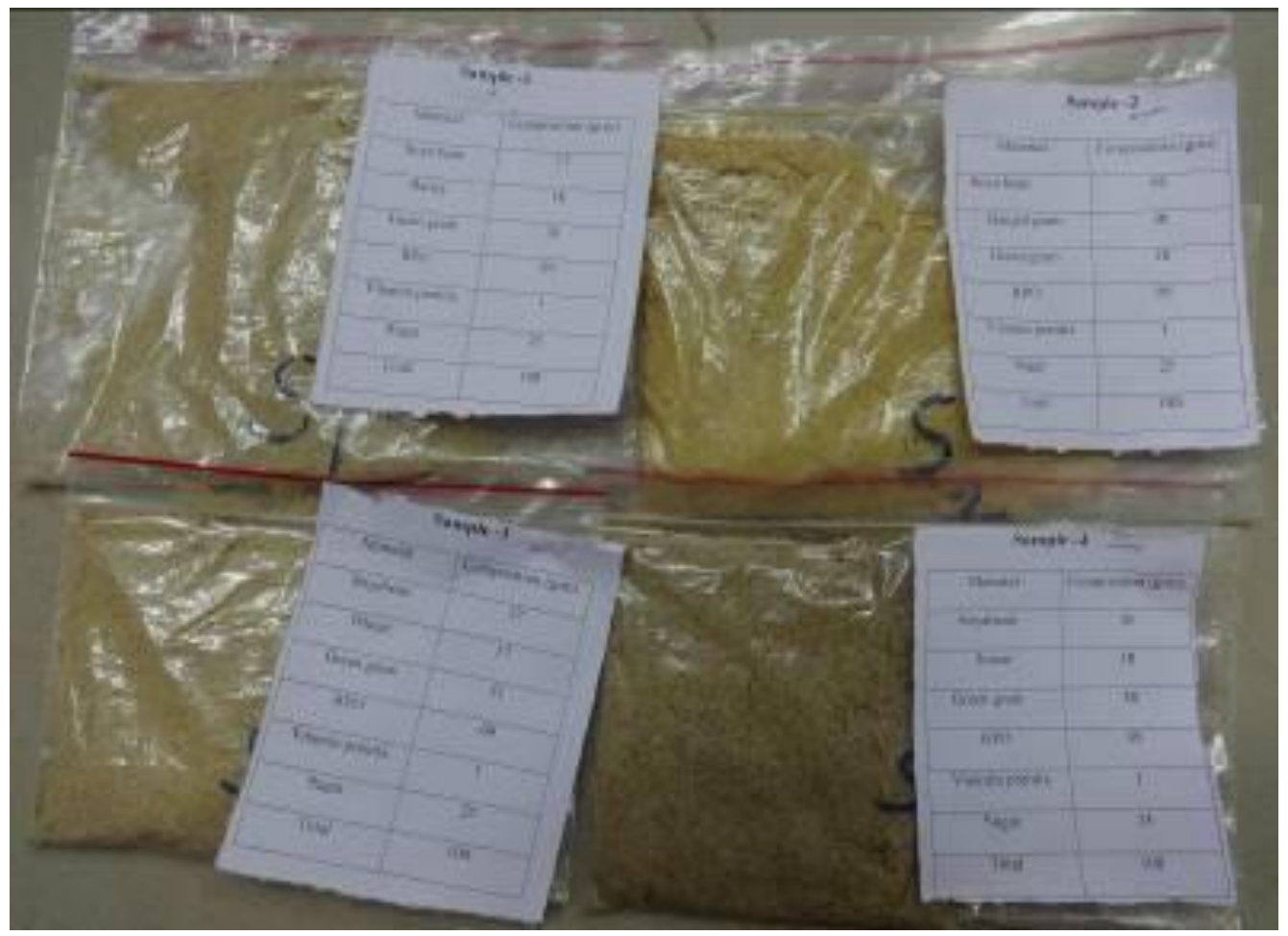

Fig.8 Variations of protein values in different samples

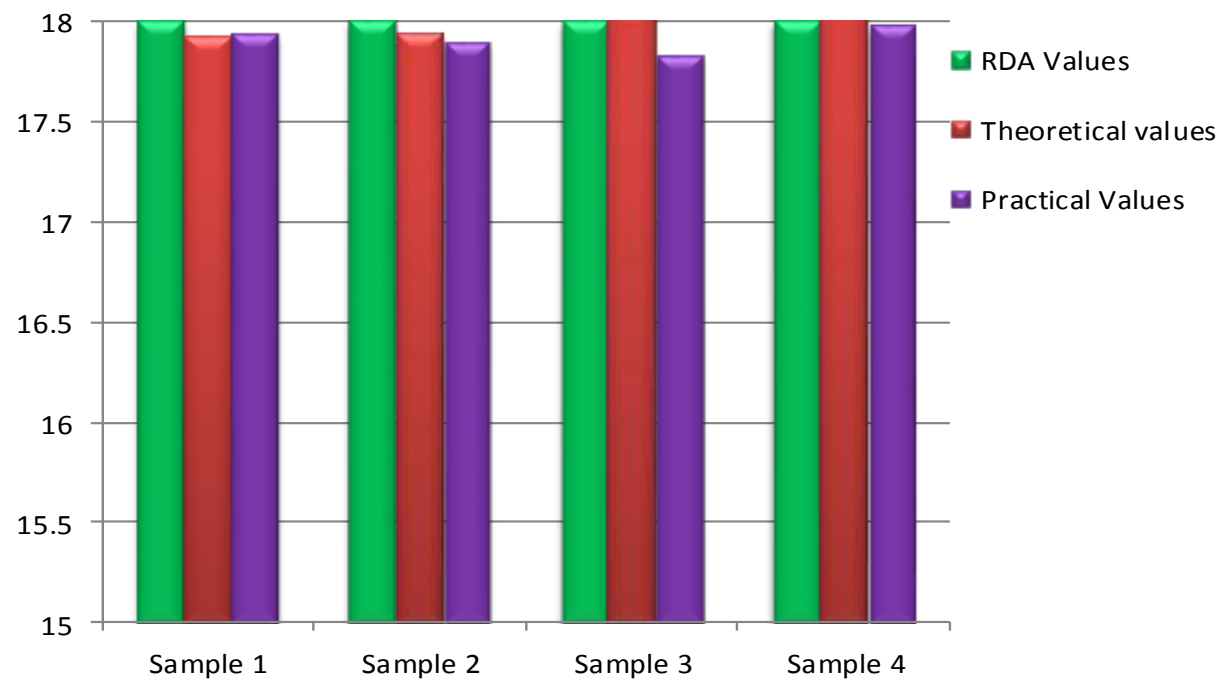


Fig.9 Variations of Fat values in different samples

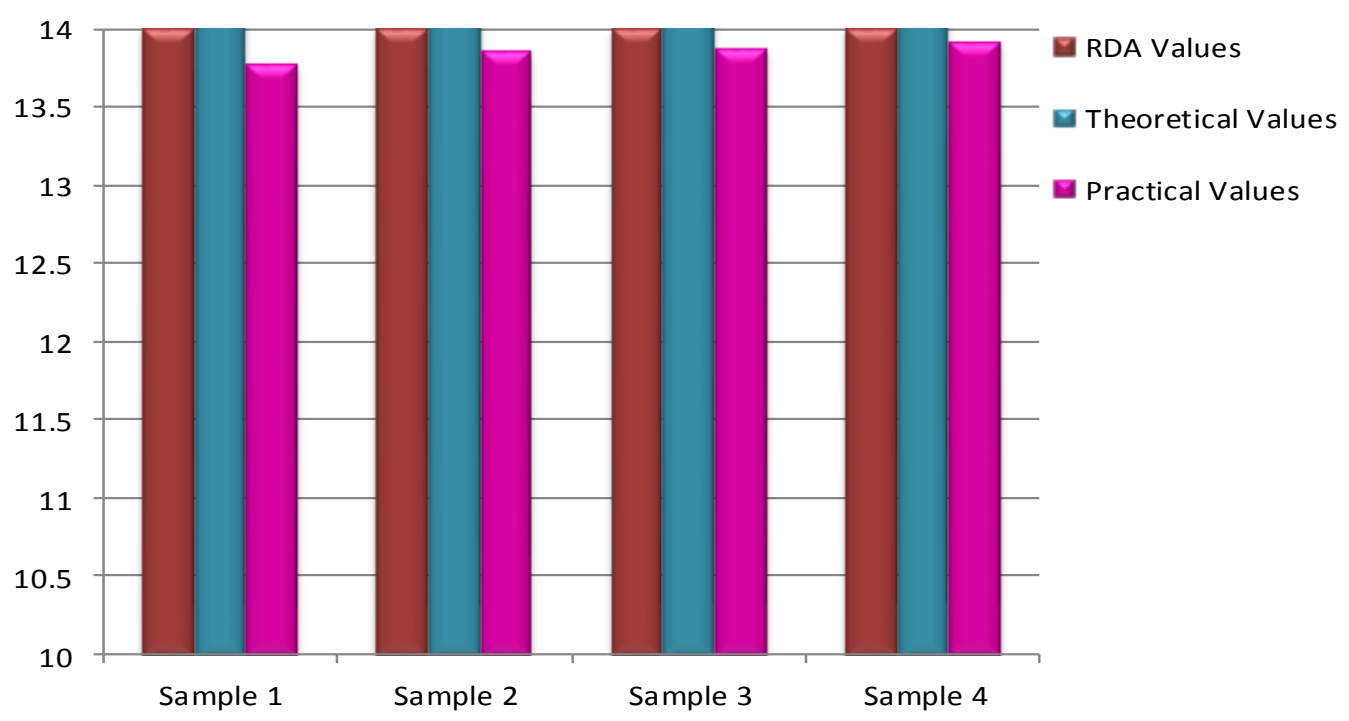

Fig.10 Variations of Carbohydrate values in different sample

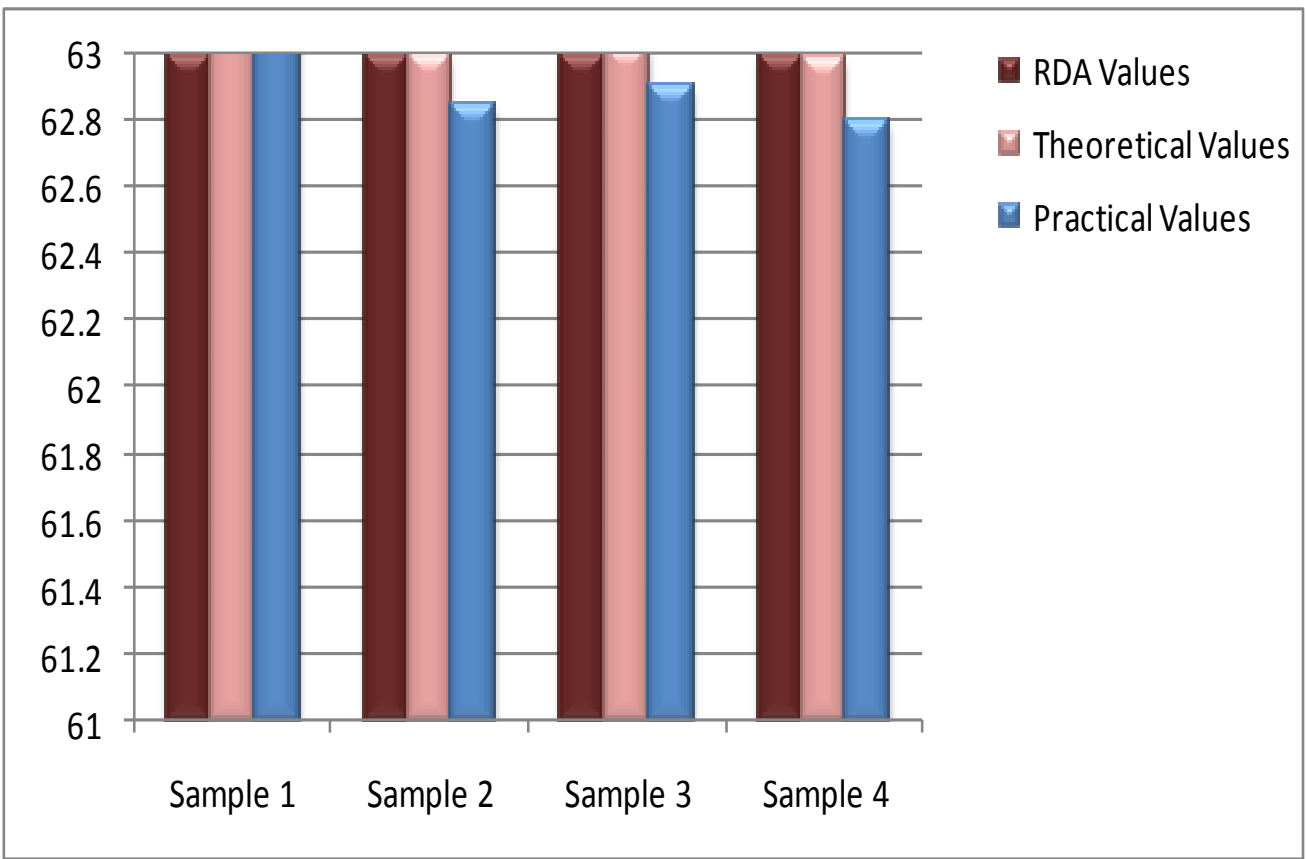


Fig.11 Variations of energy values in different samples

450

448

446

444

442

440

438

436

434

432

430

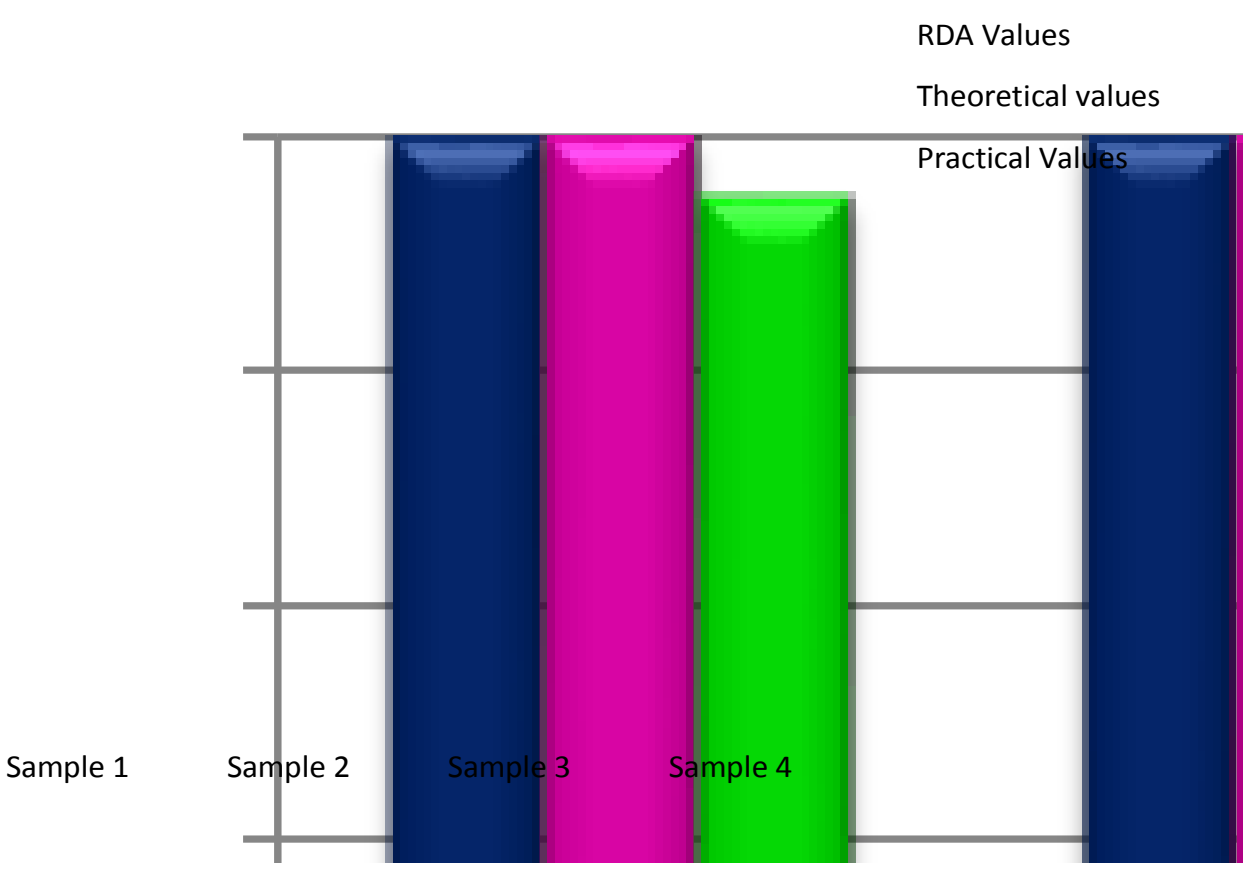

Fig.12 Sensory evaluation in Therapeutic Food Samples

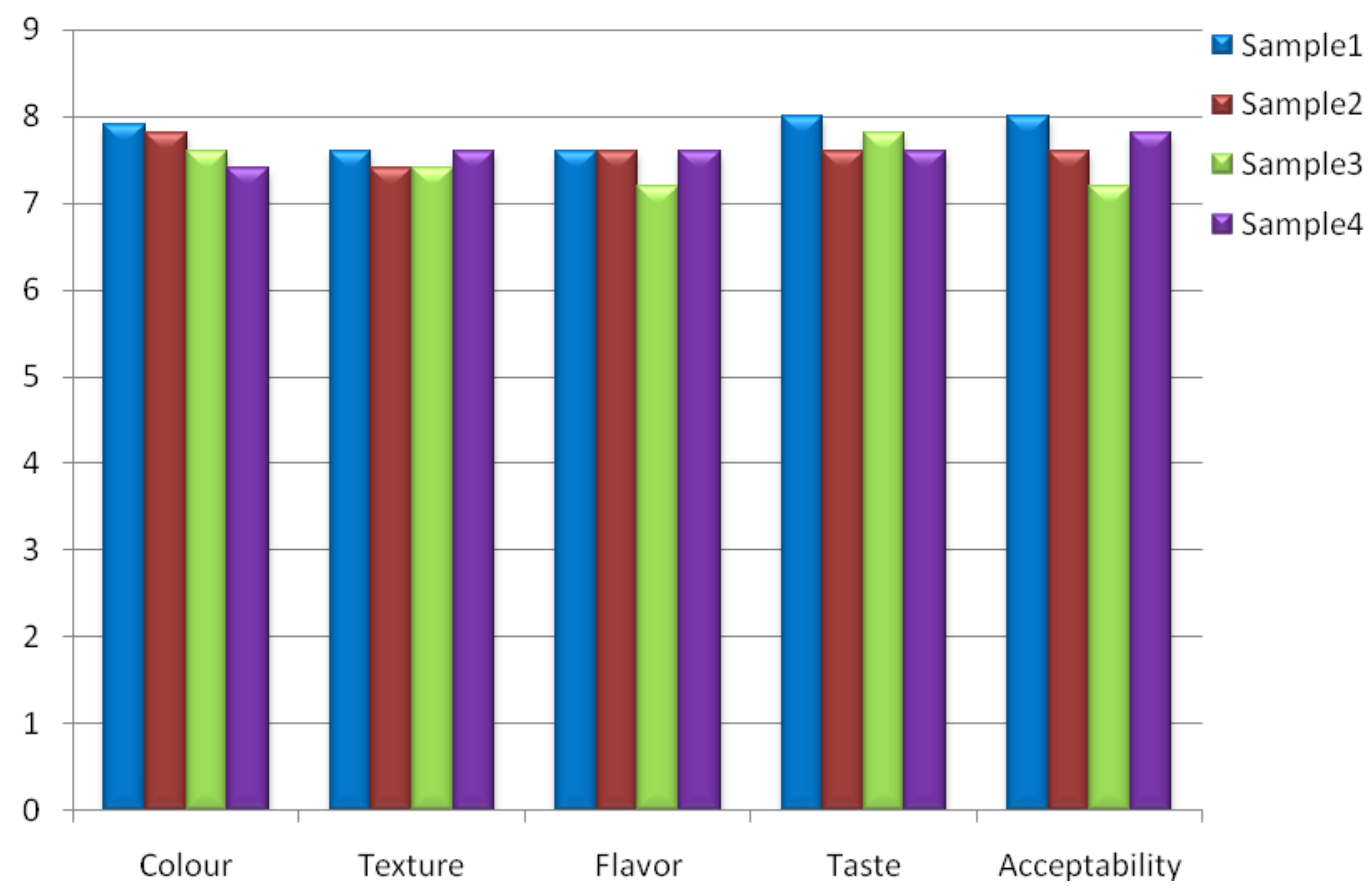




\section{Carbohydrates content}

The carbohydrates contents of sample1, sample 2, sample 3, sample 4 after analyzing were found to be $63.15,62.85,62.9$, 62.83 grams respectively whereas theoretically they were estimated to be 63.2, 63.703, 63.018 , and $62.992 \mathrm{~g}$ respectively.

The carbohydrates content for therapeutic food for adolescent girls should be 63g for which helps in active release of enzymes for required growth. Theoretically, we have tried to the maximum to keep the Carbohydrates content to $63 \mathrm{~g}$. We obtained almost closely to 63g. Among the four samples, sample 3 obtained the maximum value, $63.7 \mathrm{~g}$ and sample 3 was the least, 62.992g. Practically, among the four samples, we obtained the maximum value for sample 3, (62.9g).we obtained the least value for sample 4, $(62.83 \mathrm{~g})$. The variations of carbohydrates content of various samples is shown in Figure 10. There was no significant difference found in between theoretical and practical values for moisture content which was found by the student t-test.

\section{Energy content}

The energy contents of sample1, sample 2, sample 3, sample 4 after analyzing were found to be $447.3,446.6,447,447.9 \mathrm{kcal}$ respectively whereas theoretically they were estimated to be 452.56, 454.332, 452.703, $451.214 \mathrm{kcal}$ respectively. The recommended energy content for therapeutic food for adolescent girls is $450 \mathrm{kcal}$. The energy contents of different samples were plotted graphically in a bar graph for in-depth watch of variations among the four samples which are formulated with different ingredients. Theoretically, we have tried to the maximum to keep the energy content to $450 \mathrm{kcal}$. We obtained almost closely to $450 \mathrm{kcal}$. Theoretically, among the four samples, sample 4 obtained the maximum value 452 kcal and sample 2 was the least (450.332 kcal). Practically, among the four samples, we obtained the maximum value for sample 4 , (447.9). We obtained the least value for sample 2, (446.6 kcal). The variations of energy levels of various samples are shown in Figure 11.

There was no significant difference found in between theoretical and practical values for moisture content which was found by the student t-test.

\section{Sensory analysis}

Sensory Analysis is generally done to test sensory parameters like taste, colour, texture, flavor and overall acceptability. We tested all these sensory attributes by a panel of 5 members in College of Agricultural Engineering, Madakasira, Anantapur Dist. The average values were considered as the final values. The opinions were pictorially depicted with the help of a bar graph (Fig. 12).

Sample 1 was found highly acceptable on grounds of colour. In terms of taste also, sample 1 acceptability was found to be good after sample 1. All the samples were almost equivalent in flavor.

Summary and Conclusions are as follows:

The present study was undertaken for the preparation and evaluation of a therapeutic food for Adolescent girls formulated with Bengal gram, Soya bean, Barley, Green gram, wheat and Ragi. Experiments were carried out in the Quality control lab, Andhra Pradesh Foods Pvt. Ltd. The therapeutic food was prepared from Soya bean, Bengal gram, Barley, green gram, wheat and Ragi in different compositions. Therapeutic food Samples were prepared according to the RDA 
requirements for adolescent girls. These samples prepared were analysed to study their chemical composition and overall acceptability. The formulation with Soya bean, Ragi and Green gram of $16 \mathrm{~g}, 18 \mathrm{~g}, 30 \mathrm{~g}$ respectively (sample 4) has attained the high levels of nutritional properties values but its organoleptic properties values were lower. The formulation with composition of $17 \mathrm{~g}$ of soya bean, $18 \mathrm{~g}$ of barley and $30 \mathrm{~g}$ of green gram (sample1) has attained highest acceptability in terms of hedonic rating (Sensory evaluation). The overall acceptability of Sample1 was found to be high among all samples. This formulated therapeutic food (sample-1) is highly preferable to adolescent girls suffering from anemia, stomach pain and nerves weakness patients as the food contains high amount of protein and the soya bean acts as the nutritional supplement to the growing adolescents.

\section{References}

Albertson AM, Affenito SG and Bauserman R. (2009) The relationship of ready-toeat cereal consumption to nutrient intake, blood lipids, and body mass index of children as they age through adolescence. J Am Diet Assoc 109, 1557-1765.

Albertson AM, Anderson GH and Crockett SJ. (2003) Ready-to-eat cereal consumption: its relationship with BMI and nutrient intake of children aged 4 to 12 years. J Am Diet Assoc 103, 1613 1619

Barton BA, Eldridge AL and Thompson D. (2005) The relationship of breakfast and cereal consumption to nutrient intake and body mass index: the National Heart, Lung, and Blood Institute Growth and Health Study. J Am Diet Assoc 105, 1383-1389.

Bertrais S, Polo Luque ML and Preziosi P.
(2000) Contribution of ready-to-eat cereals to nutrition intakes in French adults and relations with corpulence. Ann Nutr Metab 44, 249-255.

Gibson S (2003) Micronutrient intakes, micronutrient status and lipid profiles among young people consuming different amounts of breakfast cereals: further analysis of data from the National Diet and Nutrition Survey of Young People aged 4 to 18 years. Public Health Nutr 26, 815-820.

Gibson SA and Sullivan KR (1995) Breakfast cereal consumption patterns and nutrient intakes of British schoolchildren. J R Soc Health 115, 366-370.

Gross LS, Li L and Ford ES. (2004) Increased consumption of refined carbohydrates and the epidemic of type 2 diabetes in the United States: an ecologic assessment. Am J Clin Nutr 79, 774779.

Kafatos A, Linardakis M and Bertsias. (2005) Consumption of ready-to-eat cereals in relation to health and diet indicators among school adolescents in Crete, Greece. Ann Nutr Metab 49, 165-172.

Koh-Banerjee P and Rimm E (2003) Whole grain consumption and weight gain: a review of the epidemiological evidence, possible mechanisms and opportunities for further research. Proc Nutr Soc 62, 25-2

Kosti RI, Panagiotakos DB and Zampelas A. (2008) The association between consumption of breakfast cereals and BMI in schoolchildren aged 12-17 years: the VYRONAS study. Public Health Nutr 11, 1015-1

Liu S (2006) Lowering dietary glycemic load for weight control and cardiovascular health: a matter of quality. Arch Intern Med 166, 1438-1439.

Ludwig DS (2002) The glycemic index: physiological mechanisms relating to 
obesity, diabetes, and cardiovascular disease. JAMA 287, 2414-242.

Montenegro-Bethancourt G, Vossenaar M and Kuijper LD. (2009) Ready-to-eat cereals are key sources of selected micronutrients among schoolchildren from public and private elementary schools in Quetzaltenango, Guatemala. Nutr Res 29, 335-342.

Nicklas TA, Neil CE and Berenson GS (1998) Nutrient contribution of breakfast, secular trends, and the role of ready-toeat cereals: a review of data from the Bogalusa Heart Study. Am J Clin Nutr 67, S757-S763.

Preziosi P, Galan P and Deheeger M. (1999) Breakfast type, daily nutrient intakes and vitamin and mineral status of French children, adolescents, and adults. J Am Coll Nutr 18, 171-178.
Suter PM (2005) Carbohydrates and dietary fiber. Handb Exp Pharmacol 170, 231261.

Van den Boom A, Serra-Majem L and Ribas L. (2006) The contribution of ready-toeat cereals to daily nutrient intake and breakfast quality in a Mediterranean setting. J Am Coll Nutr 25, 135-143.

Waller SM, Vander Wal JS and Klurfeld DM. (2004) Evening ready-to-eat cereal consumption contributes to weight management. J Am Coll Nutr 23, 316321.

Williams BM, Neil CE and Keast DR. (2009) Are breakfast consumption patterns associated with weight status and nutrient adequacy in African-American children? Public Health Nutr 12, 489496.

\section{How to cite this article:}

Sai Vinay, B.J.V., G. Rajender, Ch. Wagdevi, G. Sandya Rani and Revathi, Y.V. 2019. Development of Therapeutic Food for Adolescent Girls. Int.J.Curr.Microbiol.App.Sci. 8(06): 1622-1639. doi: https://doi.org/10.20546/ijcmas.2019.806.195 